\title{
Phytoalexin Production Elicited by Pyricularia oryzae Infection and Its Hyphal Wall-Component Treatment in Rice Leaves
}

\author{
Toshihiro Iwakuma*,**, Yuhji AtaKA*, Nobuaki Matsuyama* \\ and Satoshi WAKIMOTO*
}

\begin{abstract}
Infection of the rice blast fungus Pyricularia oryzae elicited the diterpenoid phytoalexin (PA) production in rice leaves. Striking difference in the time course of PA production was observed between incompatible and compatible race-cultivar relations. The PA production was firstly observed at $36-48 \mathrm{hr}$, in general, after inoculation in incompatible case and no production was observed at this time in compatible case. The production was sometimes detected at 12 $\mathrm{hr}$ in incompatible case. Such difference, however, disappeared in the case of the treatment with heat-killed spores of the fungus and PA production was observed at $48 \mathrm{hr}$ in incompatible and compatible cases. No elicitation of PA production was documented at the treatment with protoplasts originated from the hyphal cells of Pyricularia oryzae. Hyphal cell-wall components, especially water insoluble fraction, obtained by the fractionation of the fungal cells of compatible and incompatible races elicited excellently PA production. These results clearly verified the existence of the elicitor in hyphal cell wall.
\end{abstract}

(Received June 8, 1990)

Key words: phytoalexin production, elicitor, rice blast resistance.

\section{INTRODUCTION}

The production of phytoalexin (PA) in the rice leaves infected with Pyricularia oryzae has long been investigated. In 1983-85, Oryzalexin $\mathrm{A}\left(\mathrm{C}_{20} \mathrm{H}_{30} \mathrm{O}_{2}, \mathrm{MW} 302\right), \mathrm{B}\left(\mathrm{C}_{20} \mathrm{H}_{30} \mathrm{O}_{2}, \mathrm{MW}\right.$ 302) and $\mathrm{C}\left(\mathrm{C}_{20} \mathrm{H}_{28} \mathrm{O}_{2}\right.$, MW 300) were successively isolated by Akatsuka et al. ${ }^{1,2)}$ from the surrounding tissues of susceptible blast lesions. During this time, Matsuyama and Wakimoto newly isolated diterpenoid PA which is different from the Oryzalexins stated above from the blastinfected lower rice leaves where the resistant lesions are predominant and named as $\mathrm{S}-1^{11,12}$. The molecular formula and weight of this substance were decided as $\left(\mathrm{C}_{20} \mathrm{H}_{32} \mathrm{O}_{2}\right.$ and MW 304) by high resolution mass spectrometry (HR-MS) analysis ${ }^{12}$. These substances were assumed to associate with the blast-resistance in aged lower leaves ${ }^{11,13)}$. In 1986, the existence of similar substance was reported by Sekido et al. ${ }^{18)}$ and named as Oryzalexin D. These substances were also produced at UV irradiation and at treatments with some chemicals ${ }^{14,16)}$. Time course of these diterpenoids production after inoculation of compatible and incompatible races was formerly studied by the authors using gas-liquid chromatography (GLC) ${ }^{13)}$. These experiments, however, were conducted for whole infected leaves and more detailed studies were required. In this experiment, the time course of PA production elicited by the rice blast fungus infection to compatible and incompatible rice cultivars and the elicitation with the fungal hyphal cell-wall

* Laboratory of Plant Pathology, Faculty of Agriculture, Kyushu University, Fukuoka 812, Japan 九州大学農学部

** Present address: Mii Agriculture Extension Service, Kitano-machi, Fukuoka 830-11, Japan 現在: 福岡県三井農業改良普及所 
components were tested. The abstract was reported elsewhere ${ }^{7)}$ and details will be contributed in this report.

\section{MATERIALS AND METHODS}

Rice plants. Cultivars Aichiasahi (Pi-a), Kinmaze (Pi-a) and Kanto No. 51 (Pi-k) were used. Rice plants were routinely raised in a greenhouse. Unless otherwise stated, 7th uppermost leaves were used for the experiments.

Inocula. Four isolates of Pyricularia oryzae Cavara: Naga 69-150 (race 007) and TH 67-22 (race 131), Naga 87 (race 131) and Ken 53-33 (race 137) were used. The isolates were cultured on oat meal agar in petri dishes at $25 \mathrm{C}$ for 10 days and kept them under BLB lamp for more 2 days taking off the lid and wrapping the surface with polyethylene film. Spore suspension was adjusted to be $15-20$ spores under $\times 150$ microscopic field.

Inoculation and treatment. The leaf blade was cut to $25 \mathrm{~cm}$ in length and injured by punch inoculation apparatus ${ }^{10)}$ (30 spots/leaf blade, Kiya-seisakusho Co.) just enough to injure but not hard enough to punch out a hole. Around twenty-five $\mu$ l (one drop) of the suspension of spores, protoplasts or the hyphal wall components (HWC) was placed on each spot of the leaf-blade with a micropipett and kept in a moistened plastic tray at $25 \mathrm{C}$ for $6,12,18$, 24, 36 and $48 \mathrm{hr}$.

Extraction of phytoalexin $(\boldsymbol{P A})$. The suspensions applied on the spots were collected and membrane-filtered $(0.2 \mu \mathrm{m})$ to eliminate spores or cell debris. Twenty $\mathrm{ml}$ of petroleum ether was added to $10 \mathrm{ml}$ of the filtrate and shaked vigorously in a $50 \mathrm{ml}$ separation funnel, respectively. The ether layer was concentrated, transferred to a small cone-shaped silyl vial and evaporated with $\mathrm{N}_{2}$ gas blowing. Then the vial was sealed tightly and $50 \mu \mathrm{l}$ of ethylacetate was poured by a microsyringe through silicone-rubber sealing. The sample was carefully dissolved and $5 \mu$ l of this sample solution which is equivalent with the extract from 39 spots on the rice leaf-blade was subjected to GLC with OV-17 column.

Gas-liquid chromatography $(\boldsymbol{G L C})$. GLC was conducted by Shimazu 7AG with flame ionization detector (FID) using the column of OV-17 (1\% loading on Gas Chrom Q, 100 120 mesh, in $150 \times 0.3 \mathrm{~cm}$ silanized glass column) at $210 \mathrm{C}$ under $30 \mathrm{ml} / \mathrm{min}$ of $\mathrm{N}_{2}$ gas flow rate. S-1 ${ }^{11,12)}$ was used as the standard of diterpenoid phytoalexin. In this GLC condition the diterpenoid PAs (S-1 and its derivatives) appear at the same position on the GLC chromatogram as a single peak ( $c a$. Rt. $10 \mathrm{~min}$ ). Therefore, the peak arrowed in the Figs. 1 and 2 represents the total amount of the diterpenoid PAs produced.

In the sugar analysis of hyphal cell-wall fractions, each fraction was previously hydrolysed with $1 \mathrm{~N} \mathrm{HCl}$ at $100 \mathrm{C}$ for $3 \mathrm{hr}$ and then trimethylsilyl (TMS)-derivatized with hexamethyldisilazane (HMDS) and trimethylchlorosilane (TMCS), routinely. GLC was conducted with Silicone SE-52 column [3\% loading on Chromosorb W (AW-DMCS), $60-80$ mesh, in $300 \times 0.3$ $\mathrm{cm}$ glass column] at 140-210 C (gradient) under $50 \mathrm{ml} / \mathrm{min}_{2}$ gas flow rate.

Hyphal protoplasts. Isolate Naga 69-150 and TH67-22 were shake-cultured in liquid Vogel's medium ${ }^{20)}$ at $25 \mathrm{C}$ for 5 days. The mycelial bodies were obtained by centrifugation $(2,000 \times g, 10 \mathrm{~min})$, and suspended in the membrane-filtered $(0.2 \mu \mathrm{m})$ stabilizing medium $(0.22$ M sodium phosphate buffer, $0.6 \mathrm{M} \mathrm{KCl}, 2.0 \mathrm{mM} \mathrm{MgCl}_{2}, \mathrm{pH} \mathrm{7.0)}$ and washed by centrifugation $(2,000 \times g, 10 \mathrm{~min})$. The mycelial bodies were suspended in the membrane-filtered lytic-enzymes solution [10 ml the stabilizing solution, $20 \mathrm{mg}$ Cellulase Onozuka R-10 (Kinki Yakult MFG Co., Ltd.), $15 \mathrm{mg}$ Zymolyase $20 \mathrm{~T}$ (Seikagaku Kogyo Co. Ltd.), pH 5.5] and shaked (20 SW/ $\mathrm{min}$ ) at $28 \mathrm{C}$ for $3 \mathrm{hr}$ in L-shape tubes. After filtration twice through tissue paper (J. Kimberly Wipers S-200) and centrifugation $(400 \times g, 5 \mathrm{~min})$, precipitated protoplasts were suspended in the stabilizing solution stated above and centrifuged $\left.(400 \times g, 5 \mathrm{~min})^{6}\right)$. This treatment was repeated for 2 times. Finally, protoplasts suspended in the stabilizing solution were adjusted to be $2.0 \times 10^{5} \mathrm{cells} / \mathrm{ml}$. All processes were conducted aseptically. This protoplast suspension 
was placed on the injured spots of the rice leaf-blade (cv. Kinmaze). The stabilizing solution and distilled water were also applied on the leaves as the two kinds of check. The PA production was estimated routinely by GLC analysis at $48 \mathrm{hr}$ after the treatment.

Hyphal cell-wall components $(\boldsymbol{H W C})$. The isolates were cultured in modified Richards medium (3.0 g KNO $, 0.5 \mathrm{~g} \mathrm{KH}_{2} \mathrm{PO}_{4}, 0.5 \mathrm{~g} \mathrm{~K}_{2} \mathrm{HPO}_{4}, 0.5 \mathrm{~g} \mathrm{MgSO}_{4}, 1.0 \mathrm{mg} \mathrm{CaCl}$, $1.0 \mathrm{mg} \mathrm{FeCl}{ }_{3}, 1.0 \mathrm{mg}$ thiamine, $1.0 \mathrm{mg}$ biotin, $20.0 \mathrm{~g}$ glucose $\left./ 1, \mathrm{pH} 5.7\right)$ at $27 \mathrm{C}$ for 14 days. The fractionation of cell-wall components was conducted by the modified method of Nakajima et al. ${ }^{17)}$ The mycelial mat was washed repeatedly with water followed by acetone. The mat was freeze-dried and ground in the mortar. This powdery fraction was designated as Fraction I (Fr. I). This Fr. I was suspended in $0.1 \mathrm{M}$ phosphate buffer ( $\mathrm{pH} 7.0$ ), homogenized and autoclaved at $121 \mathrm{C}$ for $20 \mathrm{~min}$. After centrifugation $(7,000 \times \mathrm{g}, 10 \mathrm{~min})$, the pellet was resuspended in the phosphate buffer stated above, autoclaved and centrifuged. The supernatants were combined and subjected to further fractionation. Methanol was added to this supernatant to be $75 \%$ final concentration and kept overnight at $4 \mathrm{C}$. After centrifugation $(3,500 \times g, 10$ $\mathrm{min}$ ), the pellet obtained was dissolved in water and dialyzed at $4 \mathrm{C}$ overnight against distilled water. The inner dialyzate was concentrated, freeze-dried and designated as Fr. II. A part of Fr. II was dissolved in water and $7 \%$ cetyltrimethylammonium bromide (Cetavlon) solution was added. After keeping at $30 \mathrm{C}$ overnight, the supernatant was obtained by centrifugation $(3,500 \times \mathrm{g}, 10 \mathrm{~min})$. Half volume of $1 \%$ boric acid was added to the supernatant and then $\mathrm{pH}$ value was adjusted carefully to $\mathrm{pH} 8.9$ with $1 \mathrm{~N} \mathrm{NaOH}$ and kept overnight at $4 \mathrm{C}$. After centrifugation $(800 \times g, 10 \mathrm{~min})$, pellet was dissolved in $2 \mathrm{M}$ acetic acid. Then, methanol was added to this solution to be $75 \%$ final concentration and kept overnight at $4 \mathrm{C}$. The precipitate resulted was collected by centrifugation $(3,500 \times g, 10 \mathrm{~min})$ and freeze-dried. This fraction was designated as Fr. III. The residual fraction after the autoclaving in $0.1 \mathrm{M}$ phosphate buffer at first step of the fractionation was suspended in water, dialyzed against distilled water at 4 $\mathrm{C}$ overnight, centrifuged and freeze-dried. This fraction was designated as Fr. IV.

These fractions were dissolved or suspended in distilled water and subjected to the leaf-blade of various cultivars. The eliciting activity for PA production was estimated routinely at 48 $\mathrm{hr}$ after the treatment. Fraction I (freeze-dried whole cells) was suspended in distilled water at the concentration of $3 \mathrm{mg} / \mathrm{ml}$. The constitution ratio of each fraction (Fr. II-IV) in the whole cells (Fr. I) was calculated and each fraction was dissolved or suspended (Fr. IV) proportionally in water.

Microscopic observation of infected or treated sites. The leaf tissues of infected or treated sites were observed with light-microscope directly or after treatment by lactophenol method $^{19)}$.

\section{RESULTS AND DISCUSSION}

Recent studies on the rice blast disease caused by Pyricularia oryzae clarified the existence of various novel diterpenoid phytoalexins (PA) in the blast-infected rice leaves ${ }^{1,2,11-15,18)}$. Authors previously reported that these phytoalexins were produced more in aged lower rice leaves than young upper leaves and the amounts closely correlated with the degree of the age-related blast resistance ${ }^{11,13)}$. The association of the PA with race-specific blast resistance was also investigated, formerly ${ }^{13}$.

In this experiment, the PA production in rice leaves was examined by the punch inoculation method $^{10)}$. Although this method involves the mechanical injuring in the inoculation process and seems to be unnatural, it is convenient to estimate quantitatively the PA production at fixed area and position of rice leaves.

It is well known that the rapidity of PA production at the infection is faster in incompatible race-cultivar relation than that of compatible relation. Same result was obtained in this experiment. In incompatible relation, the PA production was detected at 36-48 $\mathrm{hr}$ after in- 

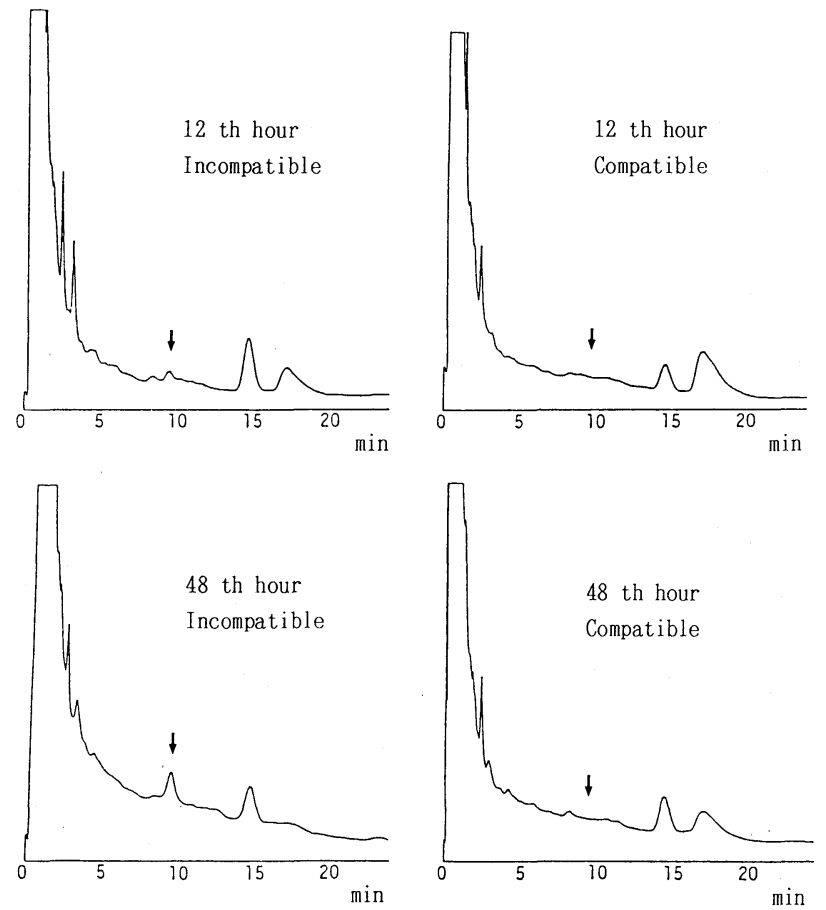

Fig. 1. Diterpenoid phytoalexins production at 12th and 48th hr after inoculation of Pyricularia oryzae Cav. in incompatible and compatible race-cultivar relation. Arrows indicate the retention time of the standard (S-1, Rt. 9.9 min). Cultivar: Kinmaze, Inocula: TH67-22 (incompatible) and Naga69-150 (compatible). GLC was conducted by Shimazu GC-7AG with OV-17 column at $210 \mathrm{C}$ under $30 \mathrm{ml} / \mathrm{min}_{2}$ flow rate.

oculation at which the insertion of the infection hyphae had started. At this time, PA was not detected in compatible relation. Sometimes, the production of PA was observed at $12 \mathrm{hr}$ in incompatible case when the leaves of 10th-leaf stage were inoculated (Fig. 1). In other experiments with bioassay ${ }^{16}$, the production of PA was detected at $6 \mathrm{hr}$ after inoculation, the time of spore germination, in incompatible case. The difference between the results of GLC and bioassay could be attributable to the sensitivity of these two analytical methods. In general, the appearance of PA was 12-24 hr faster in incompatible relation than compatible relation. However, this race specificity disappeared when heat-killed $(120 \mathrm{C}, 20 \mathrm{~min})$ spores were applied and the PA appeared at $48 \mathrm{hr}$ in incompatible and compatible cases.

To examine the location of the elicitor in Pyricularia oryzae, rice leaf blade was treated with the hyphal protoplasts originated from the hyphal cells of each isolate. No PA production was observed at $48 \mathrm{hr}$ after treatment, though the protoplasts reverted to the normal hyphae by this time. This result indicated that the elicitor might exist in hyphal cell-wall like the case of other disease $\mathrm{e}^{3-5)}$. The reasons why no elicitation of PA was observed by $48 \mathrm{hr}$ after the protoplast treatment in spite of the reversion of the hyphal cell-wall, could simply be attributable to the delay of elicitation by the reverted cell-wall. To certify the location directly, the hyphal cell-wall was fractionated and the eliciting ability of each fraction was estimated. The fractionation was carried out by the method of Nakajima et al. ${ }^{17)}$ which was used for the studies on the hyphal cell-wall structure of Pyricularia oryzae. Excellent PA production was observed in the case of Fr. IV treatment (Fig. 2). While comparatively small elicitation was shown in the case of other fractions. Fr. IV was prepared from Fr. I eliminating phosphate buffer-soluble 


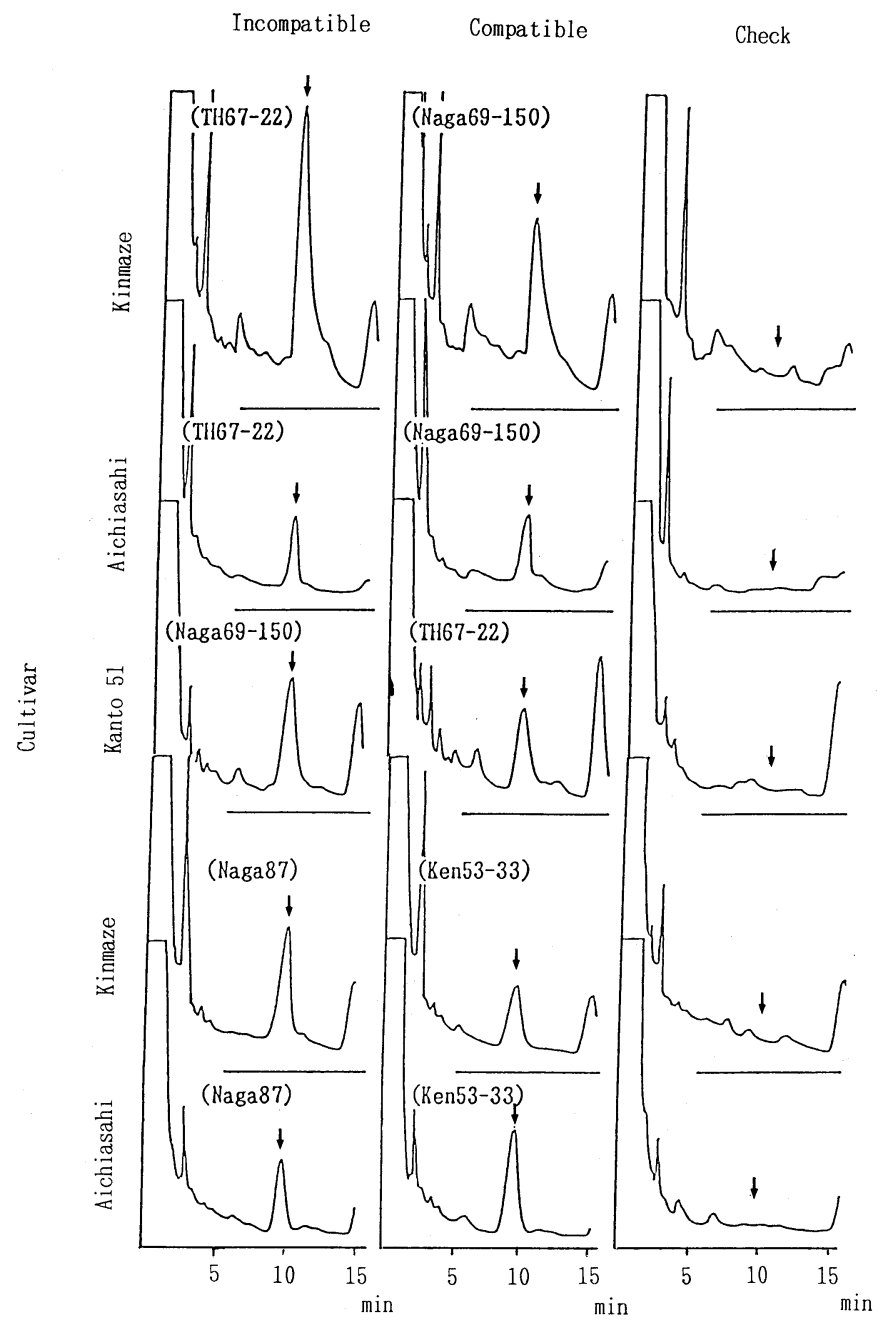

Fig. 2. Elicitation of diterpenoid phytoalexins production with hyphal cell-wall component (Fr. IV) obtained from various races of Pyricularia oryzae Cav. Arrows indicate the retention time of the standard (S-1, Rt. $9.9 \mathrm{~min})$. GLC was conducted by Shimazu GC-7AG with OV-17 column at $210 \mathrm{C}$ under $30 \mathrm{ml} / \mathrm{min} \mathrm{N}_{2}$ flow rate.

fractions (proteo-glycan $e t c.)^{17)}$ and constituted with glucose, mannose, galactose and unidentified sugars. In some cases, the amount of PA elicited by Fr. IV was seemed to be abundant in incompatible relation (Fig. 2). While, the reverse result was also observed in compatible case such as Ken 53-33-cv. Aichiasahi. These results could indicate the absence of the specificity in each elicitor. However, the fractionation methods employed in this experiment involved the autoclaving which could denature the delicate structures and so, further studies with more mild procedures will also be required before the final conclusion.

Iwata et al. isolated the water soluble glycoprotein (MW ca. 27,600) which stimulates peroxidase activity in rice leaves from the mycelial bodies of Pyricularia oryzae ${ }^{8,9)}$. It is uncertain if this peroxidase elicitor could also elicit PA production. Since this glycoprotein was water soluble and so, it will relate with Fr. II and III which showed a weak eliciting activity for PA production.

In this experiment, the close association of phytoalexins with race-specific rice blast re- 
sistance was elucidated by the time course study on PA production. The race specificity in PA elicitation was only observed when living spores were applied and not at the treatments with heat-killed spores or the hyphal cell-wall components. It is uncertain now if suppressor ${ }^{4)}$ or suppressing system in living fungal cells could exist. This is the subject for future study.

\section{Literature cited}

1. Akatsuka, T., Kodama, O., Kato, H., Kono, Y. and Takeuchi, S. (1983). Agric. Biol. Chem. 47: 445-447.

2. Akatsuka, T., Kodama, O., Sekido, H., Kono, Y. and Takeuchi, S. (1985). Ibid. 49: 1689-1694.

3. Doke, N., Garas, N.A. and Kúc, J. (1979). Physiol. Plant Pathol. 15: 127-140.

4. Garas, N.A., Doke, N. and Kúc, J. (1979). Ibid. 15: 117-126.

5. Doke, N. and Tomiyama, K. (1980). Ibid. 16: 169-176.

6. Ishizaki, H., Ohkuma, T., Yamaoka, N. and Kunoh, H. (1987). J. Pesticide Sci. 12: 57-63.

7. Iwakuma, T., Matsuyama, N. and Wakimoto, S. (1990). Ann. Phytopath. Soc. Japan 56: 106 (Abstr.).

8. Iwata, M., Iwamatsu, H., Suzuki, Y., Watanabe, T. and Sekizawa, T. (1982). Ibid. 48: 267-274.

9. Iwata, M., Hirose, I., Nishiide, K., Zushi, A., Watanabe, T., Sekizawa, T., Seto, H. and Ootake, N. (1984). Ibid. 50: 385 (Abstr.).

10. Matsuyama, N. and Rich, S. (1974). Phytopathology 64: 429-430.

11. Matsuyama, N. and Wakimoto, S. (1984). Ann. Phytopath. Soc. Japan 50: 379-382.

12. Matsuyama, N. and Wakimoto, S. (1985). Ibid. 51:498-500.

13. Matsuyama, N. and Wakimoto, S. (1987). Ibid. 53: 84 (Abstr.).

14. Matsuyama, N. and Wakimoto, S. (1987). Ibid. 53: 449-453.

15. Matsuyama, N. and Wakimoto, S. (1988). Ibid. 54: 183-188.

16. Matsuyama, N. (1990). Papers of 25th Symposium on Physiological Plant Pathology in Japan. p. 18.

17. Nakajima, T., Tamari, K. and Matsuda, K. (1977). J. Biochem. 82: 1647-1655.

18. Sekido, H., Endo, T., Suga, R., Kodama, O., Akatsuka, T., Kono, Y. and Takeuchi, S. (1986). J. Pesticide Sci. 11: 369-372.

19. Peng, Y.-L., Shishiyama, J. and Yamamoto, M. (1986). Ann. Phytopath. Soc. Japan 52: 801-808.

20. Vogel, H.J. (1977). The American Naturalist 98: 435-446.

\section{和 文 摘 要}

岩郎俊浩・安高雄治・松山宣明・脇本 哲：いもち病菌感染拉よび菌体壁分画処理によるイネ葉中のファ イトアレキシン生成誘導

いもち病菌感染によりイネ葉中にはジテルペン系ファイトアレキシン $(\mathrm{PA})$ が生成されるが，その経時的 変化は非親和性拉よび親和性組合せで明らかに異なっている。ガスクロマトグラフィーによる検出では, 接 種後 36 48 時間目に非親和性組合せでのみ PA 生成が観察された。また，ときには 12 時間目に検出される 場合が認められた。しかしこのレース特異性は胞子の加熱殺菌処理により消失し, 親和性, 非親和性にかか わらず 48 時間目に PA 生成がみられた。一方，菌体プロトプラストで処理した場合にはまったく生成が認 められなかった。また，いもち病菌菌体壁分画には PA 生成のエリシター活性が認められるが，なかでも菌 体を磨砕後りン酸緩衝液中でオートクレーブ処理した難溶性分画にきわめて高い活性がみられた。これらの 結果はエリシターが菌体壁に存在することを明らかに示している。 